\title{
Influence of TH1/TH2 Switched Immune Response on Renal Ischemia-Reperfusion Injury
}

\author{
Vilmar Paiva Marques ${ }^{\mathrm{a}, \mathrm{b}}$ Giselle Martins Gonçalves ${ }^{\mathrm{a}}$ Carla Quarin Feitoza ${ }^{\mathrm{a}}$ \\ Marcos Antonio Cenedeze ${ }^{a}$ Ana Paula Fernandes Bertocchi ${ }^{a} \quad$ Marcio Jose Damião $^{a}$ \\ Helady Sanders Pinheiro ${ }^{c}$ Vicente Paula Antunes Teixeira ${ }^{b}$ Marlene Antônia dos Reis ${ }^{b}$ \\ Alvaro Pacheco-Silva ${ }^{a}$ Niels Olsen Saraiva Câmara ${ }^{a, d}$ \\ a Laboratório de Imunologia Clínica e Experimental, Division of Nephrology, Universidade Federal de São Paulo, \\ Escola Paulista de Medicina, São Paulo, b Department of Pathology, Universidade Federal do Triangulo Mineiro, \\ Uberaba, and ${ }^{\mathrm{C}}$ Division of Nephrology, Universidade Federal de Juiz de Fora, Minas Gerais, and ${ }^{\mathrm{d}}$ Department of \\ Immunology, Universidade de São Paulo, São Paulo, Brazil
}

\section{Key Words}

Ischemia and reperfusion injury $\cdot$ Th1/Th2 cytokines •

Heme oxygenase 1

\begin{abstract}
Background/Aims: Recent evidence shows a critical role of the CD4+ T cell with the Th1/Th2 paradigm as a possible effector mechanism in ischemia and reperfusion injury. We hypothesize that a polarized Th1 activation response may negatively influence the renal IRI through its relationship with chemokine production (MCP-1) and with a protective tissue response (HO-1). Methods: We subjected mice to renal ischemia for 45 min using IL-4 and IL-12 knockout C57BL/6. We then measured serum urea levels, performed histomorphometric analysis for tubular necrosis and regeneration, and evaluated the mRNA expression of $\mathrm{HO}-1, \mathrm{t}-$ bet, Gata- 3 and MCP- 1 by real-time PCR at 24, 48 and $120 \mathrm{~h}$ after surgery. Results/Conclusions: The IL-4 knockout mice had a statistically significant rise in serum urea levels post IRI compared with control animals. The IL-12-deficient mice
\end{abstract}

were not affected. The IL-4-deficient mice had a statistically significant increase in tubular injury and impairment in cell regeneration. The IRI in IL-4-deficient mice was accompanied by higher levels of $\mathrm{HO}-1, \mathrm{t}$-bet and later up-regulation of MCP-1. These findings suggest that the deleterious effects of the Th1 cell involve increased production of chemokines such as MCP-1.

Copyright $\odot 2006$ S. Karger AG, Basel

\section{Introduction}

Acute renal failure affects about $5 \%$ of all hospitalized patients with a very high mortality given no specific therapy, despite advances in preventive strategies and support measures $[1,2]$. Renal ischemia-reperfusion injury (IRI) is the main cause of intrinsic acute renal failure in the native kidneys, associated with mortality greater than $50 \%$ [1], as well as in transplanted kidneys where it adversely compromises both short- and long-term allograft function $[3,4]$.

\section{KARGER}

Fax +41613061234 E-Mail karger@karger.ch www.karger.com (c) 2006 S. Karger AG, Basel

$1660-2129 / 06 / 1041-0048 \$ 23.50 / 0$

Accessible online at:

www.karger.com/nee
Niels Olsen Saraiva Câmara, MD

Department of Immunology, Institute of Biomedical Science, Universidade de São Paulo Rua Prof Lineu Prestes, 1730

05508-900 São Paulo, SP (Brazil)

Tel. +55 113091 7388, Fax +55 113091 7224, E-Mail niels@nefro.epm.br 
The pathogenesis of renal IRI is complex and still not fully understood, but inflammation is currently accepted as an important pathogenic component along with contributing factors such as endothelium injury, leukocyte infiltration, reactive oxygen species production, and generation of mediators by tubular cells [5-7]. Although the neutrophils were originally focused on as the major inflammatory mediator, recent data supports a critical role of the $\mathrm{T}$ cells in experimental renal IRI [8]. Initial data supported this concept where blockage of the CD28-B7 costimulatory pathway [9-11] had been found to be protective in animal models of renal IRI. Recent data clearly demonstrated that $\mathrm{T}$ cell-deficient mice $(\mathrm{nu} / \mathrm{nu})$ are protected from renal injury post ischemia and the injury is restored after adoptive transfer of naïve T cells [12]. Furthermore, CD4 knockout mice or antibody-depleted animals are also significantly protected from renal IRI, whereas CD8 knockout mice are not [13, 14]. Finally, a naturally occurring immune response is also present in IRI, via activation of Toll-like receptor [15].

However, the effector mechanisms underlying CD4+ T cell tissue injury is obscure. It seems that $\mathrm{CD} 4+\mathrm{T}$ cells are activated in an antigen-independent way, possibly by chemokines and cytokines released by infiltrating cells. In this sense, pro-inflammatory molecules could in theory drive the naïve $\mathrm{T}$ cells to a more aggressive phenotype [8]. Classically, CD4+ T cells can be functionally differentiated into Th 1 cells that produce IFN- $\gamma$, lymphotoxin and TNF- $\alpha$ and into Th2 cells that produce IL-4, IL-5, IL-6, IL-10 and IL-13 [16]. Th1 cell differentiation is regulated by the cytokines and by transcription factors such as IL12, IL-23, IL-27, IFN- $\gamma$, STAT4 and t-bet, whereas IL-4, IL-21, STAT6, Gata-3, c-maf and NFATs (nuclear factors of activated $\mathrm{T}$ cells) regulate Th2 cell segregation $[16,17]$. Some experimental data supports the hypothesis that Th1 inflammatory pattern is pathogenic, whereas Th2 pattern is protective in renal IRI $[8,18]$. STAT6-deficient mice, with a defective Th2 phenotype, have enhanced renal dysfunction, whereas STAT4-deficient mice, with a defective Th1 phenotype, have mildly improved renal function in an experimental model of renal ischemia. This suggests that the Th1/Th2 balance plays an important role in the pathogenesis of renal IRI [18].

It is well documented today that the functional and histological organ outcomes depend not only on the nature and intensity of the aggressor, but also on the ability of the tissue to respond in a protective way. Many molecules have intrinsic cytoprotective properties that include anti-apoptotic, anti-inflammatory and anti-oxidant actions. Heme oxygenase 1 (EC 1.14.99.3) comprises three distinct genes, i.e. HO-1 (hmox1, P09601), HO-2 (hmox2, P30519) [reviewed in 19] and HO-3 (hmox3, rat; O70453) that probably does not encode a protein. HO-2 is expressed in most cell types while HO-1 is not. However, expression of HO-1 is readily increased upon organ IRI becoming the rate-limiting factor in the generation of biliverdin, $\mathrm{Fe}^{2+}$ and carbon monoxide (CO) [20-22]. Upregulation of HO-1 is also linked to anti-inflammatory actions in IRI via inhibition of monocyte chemoattractant protein 1 (MCP-1) which is responsible for recruiting monocytes to ischemic sites $[23,24]$.

We hypothesize that a polarized Th1 activation response may negatively influence the renal IRI through its relationship with chemokine production (MCP-1) and with the protective tissue response (HO-1). To address this question, IL-12-deficient mice, representing defective Th1 response and IL-4-deficient-mice, representing defective Th2 response, were subjected to renal IRI. Renal function was massively impaired in Th2-defective animals associated with higher levels of MCP-1 and t-bet expression. This relevant renal dysfunction was visible by the analyses of HO-1 mRNA expression, found higher in IL-4 knockout animals.

\section{Materials and Methods}

\section{Animals}

Isogenic male IL-12- and IL-4-deficient C57BL/6 mice (H2IA $^{\text {b) }}$, age 5-9 weeks (25-28 g), were obtained from the University of São Paulo, Brazil. All animals were housed in individual and standard cages and had free access to water and food. All procedures were previously reviewed and approved by the internal Ethical Committee of the Institution. Wild-type C57BL/6 mice, ageand sex-matched, were used as control animals and were obtained from the Federal University of São Paulo (UNIFESP, Brazil). The study was approved by the local Ethical Committee on Animal Research.

Experimental Model of Renal IRI: Surgery was performed as previously described [25]. The mice were briefly anesthetized with ketamine-xylazine (Agribrands do Brazil, São Paulo, Brazil). A midline incision was made and both renal pedicles were crossclamped. During the procedure, animals were kept well hydrated with saline and kept at a constant temperature $\left(\sim 37^{\circ} \mathrm{C}\right)$ through a heating pad device. Forty-five minutes later, the microsurgery clamps were removed. The abdomen was closed in two layers and the animals were placed in single cages, warmed by indirect light until completely recovered from anesthesia. Animals were kept under adjustable conditions until sacrificed, according to experimental protocol at 24,48 and $120 \mathrm{~h}$ after renal reperfusion. This animal model was associated with a mortality rate over 5 days of follow-up of 43, 0 and 27\% in IL-4 knockout, IL-12 knockout and wild-type animals. 


\section{Study Design}

Animals were assigned to the following groups: group 1 ( $n=10$, for each point of sacrifice), wild-type animals subjected to IRI; group 2 ( $\mathrm{n}=9$, for each point of sacrifice), IL-12 knockout animals subjected to IRI, and group 3 ( $n=10$, for each point of sacrifice), IL-4 knockout animals subjected to IRI. All animals were killed on days 1, 2 and 5 after reperfusion. Additionally, animals were subjected to the surgical procedure without renal vessel occlusion (sham; $\mathrm{n}=5$, for each point of sacrifice).

Analysis of Renal Function. Serum urea levels were used for the evaluation of renal function after IRI. Blood samples were collected at 24,48 and $120 \mathrm{~h}$ post-reperfusion from the abdominal inferior cava vein immediately before induced death. Serum samples were analyzed on a Cobas Mira Plus (Roche, Mannhein, Germany), using the urease enzymatic method for urea dosage.

Histological Morphometric Analyses. Formaldehyde-fixed paraffin sections of the kidney were stained with hematoxylin and eo$\sin (\mathrm{HE})$. Renal histomorphometric analysis was made by a 'blinded' renal histologist that evaluated and scored the percentage degrees of the tubular necrosis areas affected in the outer medulla zone, using optic light microscopy with 25 random fields counted at original magnification $\times 835$, corresponding to $145,846.7 \mu \mathrm{m}^{2} /$ field, with the help of the KS300 program (Zeiss) for the morphometric analysis.

\section{Gene Profiles}

Kidney samples were quickly frozen in liquid nitrogen. Total RNA was isolated from kidney tissue using TRIzol Reagent (Invitrogen, USA) methodology and RNA concentration was determined by spectrophotometer readings at absorbance $260 \mathrm{~nm}$. Firststrand CDNAs were synthesized using the MML-V reverse transcriptase (Promega, USA). RT-PCR was performed using the SYBR Green real-time PCR assay (Applied Biosystem, USA). Sequences of primers used were: HO-1 (sense) $5^{\prime}$-TCA GTC CCA AAC GTC GCG GT-3' and (anti-sense) 5' -GCT GTG CAG GTG TTG AGC C-3', t-bet (sense) 5' CCA GTA TCC TGT TCC CAG CC-3', (antisense) 5'-CAT AAC TGT GTT CCC GAG GTG TC-3', MCP-1 (sense) 5' -AAG AGA ATC ACC AGC AGC AGG T-3', (anti-sense) 5' -TTC TGG ACC CAT TCC TTA TTG G-3', Gata-3 (sense) 5' GCC TGT GCA AAA GAG ATT TCA GAT-3', (anti-sense) 5' TGA TTC ACA GAG CAT GTA GGC C-3', and hypoxanthine guanine phosphoribosyltransferase (HPRT) (sense) $5^{\prime}$-CTC ATG GAC TGA TTA TGG ACA GGA C-3' and (anti-sense) 5'-GCA GGT CAG CAA AGA ACT TAT AGC C-3'. Cycling conditions were as follows: $10 \mathrm{~min}$ at $95^{\circ} \mathrm{C}$ followed by 45 cycles of $20 \mathrm{~s}$ at $95^{\circ} \mathrm{C}, 20 \mathrm{~s}$ at $53.5^{\circ} \mathrm{C}$ and $20 \mathrm{~s}$ at $72^{\circ} \mathrm{C}$. Analysis used Sequence Detection Software 1.9 (SDS). The mRNA expression was normalized to HPRT abundance. Subsequently, all data was expressed relative to the expression of matched controls (sham).

\section{Statistical Analysis}

All data was described as median (ranges) unless otherwise stated. Parametric and nonparametric tests were performed irrelevant to the sample distribution considered normal or not. Different evolutions among the groups were compared using ANOVA followed by Turkey or Dunn's test for individual comparisons among groups. The null hypothesis was rejected when $p<0.05$. All statistical analyses were performed with the aid of Stata statistical software 5.0 (Stata Corporation, Tex., USA).

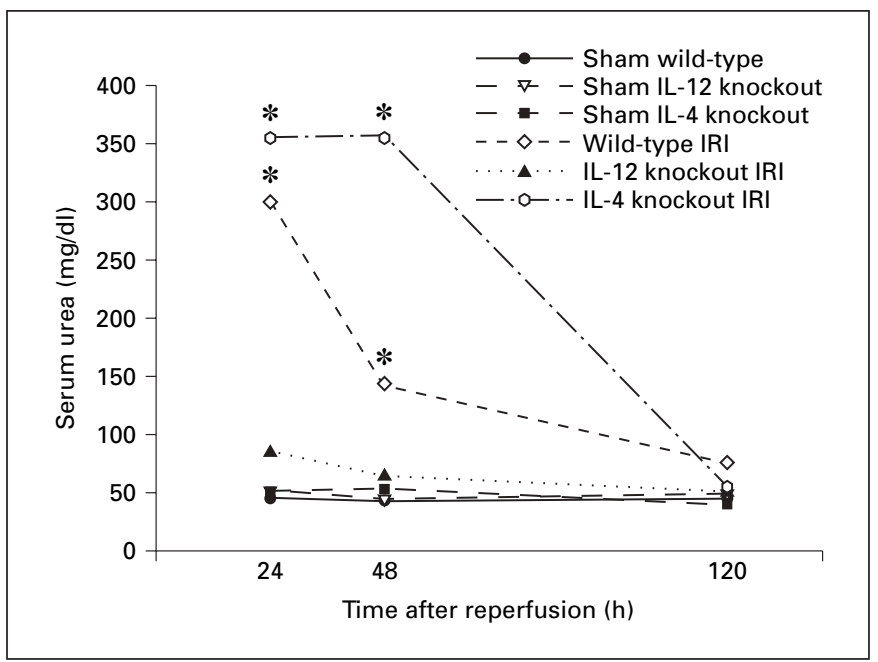

Fig. 1. IL-4-deficient mice present a major impairment in renal function. Median values of serum urea $(\mathrm{mg} / \mathrm{dl})$ in wild-type $(\diamond)$, IL-4-deficient $(\bigcirc)$ and IL-12-deficient mice $(\boldsymbol{\Delta})$ at 24, 48 and $120 \mathrm{~h}$ after renal IRI. Data of sham-operated animals are also demonstrated; wild-type ( $\bullet$ ), IL-4-deficient $(\boldsymbol{\square})$ and IL-12-deficient $(\nabla)$ presented values similar to normal. ${ }^{*} \mathrm{p}<0.05$, all compared with data from IL-12-deficient animals.

\section{Results}

\section{Integrity of Th2 Pathway Is Critically Necessary for Limiting Tissue Injury after Renal IRI}

The $\mathrm{T}$ cell effector mechanisms involved in tissue damage after renal IRI are poorly understood. Recent data support the concept that $\mathrm{T}$ and $\mathrm{B}$ cells are important effector cells; however, it is not clear how these cells got activated during this inflammatory process. Initially, we reasoned that a Th1-predominant milieu would be detrimental to tissues subjected to ischemia. We took advantage of cytokine knockout animals to address this first issue. Indeed, IL-4 knockout mice had higher serum urea levels compared with wild-type mice at $24(357 \mathrm{mg} / \mathrm{dl}, 205-452$ vs. $301 \mathrm{mg} / \mathrm{dl}, 184-381)$ and $48 \mathrm{~h}$ (357 mg/dl, 122-551 vs. $141 \mathrm{mg} / \mathrm{dl}, 75-350)$ post-ischemia $(\mathrm{p}<0.05$ at $48 \mathrm{~h})$. Conversely, IL-12-deficient mice were completely protected from IRI, compared with wild-type mice at $24 \mathrm{~h}(85 \mathrm{mg} /$ dl, 62-217), 48 (54 mg/dl, 47-59) and $120 \mathrm{~h} \mathrm{(59} \mathrm{mg/dl,}$ $59-157$ vs. $75 \mathrm{mg} / \mathrm{dl}, 54-186)$ post-reperfusion ( $<<0.05$, in all points). The urea levels measured at $48 \mathrm{~h}$ in IL-4 knockout animals were statistically different from the levels detected in wild-type animals $(p=0.013)$. It is noteworthy that the knockout sham animals presented similar serum urea levels to the normal animals $(56 \mathrm{mg} / \mathrm{dl}, 41-$ 54) (fig. 1). 


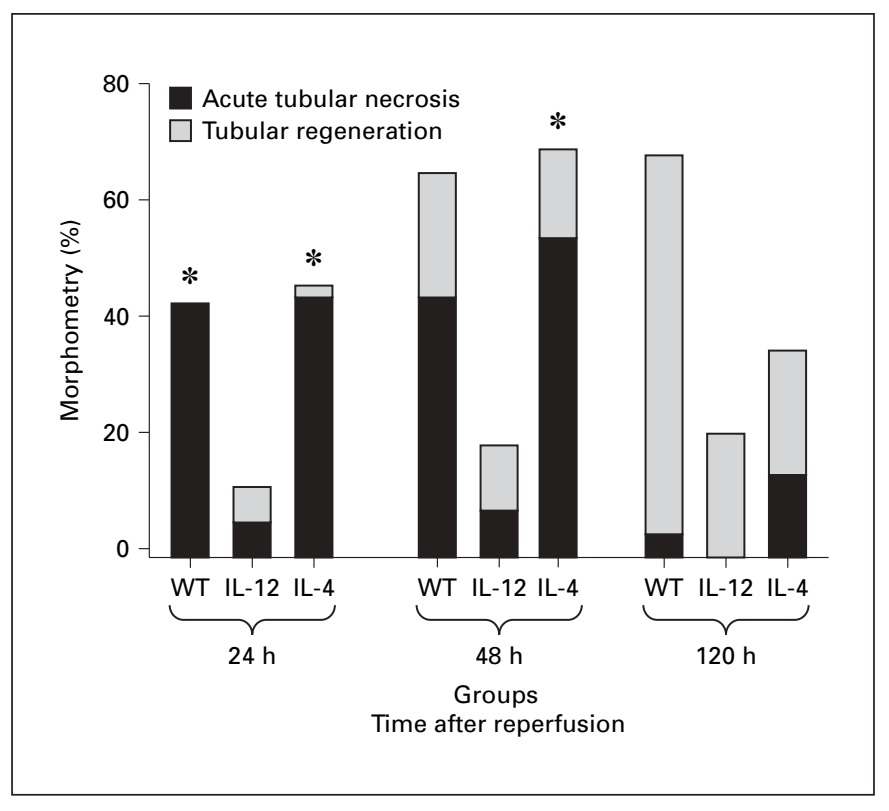

Fig. 2. IL-4-deficient animals presented a high percentage of acute tubular necrosis and impaired tubular regeneration. Median values of acute tubular necrosis (ATN, black bars) and tubular cell regeneration (grey bars) in wild-type (WT), IL-4-deficient and IL-12deficient mice at 24, 48 and $120 \mathrm{~h}$ after renal IRI. Sham-operated animals had no quantifiable acute tubular necrosis and tubular regeneration afterward (not shown in the figure). ${ }^{*} \mathrm{p}<0.05$, when percentage of ATN in wild-type and IL-4-deficient mice was compared with IL-12-deficient mice.

Impaired Cell Tubular Regeneration in the Absence of Preserved Th2 Pathway

In a mouse model, IRI is an acute event that almost resolves 5 days after reperfusion. Classically, higher degrees of tubular necrosis lead to a regeneration process that peaked at day 5 after surgery. We then questioned if the absence of a Th2 pathway would be followed by lower rates of tubular cell regeneration. Confirming our hypothesis, IL-4-deficient mice had higher levels of tubular necrosis, assessed in the outer medulla in all time points after reperfusion ( $24 \mathrm{~h}: 44 \%, 37-58$; 48 h: $54 \%$, 40-69; $120 \mathrm{~h}: 14 \%, 10-32)$, while the IL-12-deficient mice (24 h: $6 \%, 0-51 ; 48 \mathrm{~h}: 8 \%, 0-66 ; 120 \mathrm{~h}: 0.05 \%, 0-49)$ had significantly inferior levels than the control animals $(24 \mathrm{~h}$ : $43 \%, 24-50 ; 48$ h: 44\%, 18-52; 120 h: 4\%, 0-18) (p <0.05) (fig. 2). Conversely, tubular cell regeneration was severely impaired at $120 \mathrm{~h}$ after reperfusion in those IL-4-deficient animals ( $24 \mathrm{~h}: 2 \%, 0-10 ; 48$ h: 15\%, 0-60; $120 \mathrm{~h}: 21 \%, 1-$ 68 ) when compared to controls ( $24 \mathrm{~h}: 0 \%, 0-4 ; 48 \mathrm{~h}: 21 \%$, $2-35 ; 120 \mathrm{~h}: 64 \%, 9-22)$ and to the IL-12-deficient animals ( 24 h: $3 \%, 0-32 ; 48$ h: $15 \%, 0-60 ; 120$ h: $21 \%, 0-93$ ).
In sham-operated animals, we did not observe either tubular or tubular regeneration (fig. 2).

\section{Deficiency of IL-4 Is Associated with Higher mRNA Expression Levels of HO-1, MCP-1 and $t$-Bet}

$\mathrm{HO}-1$ is a stress-induced enzyme related to cytoprotection through heme degradation end-products. Although prior up-regulation of this enzyme is related to cytoprotection, its levels positively correlate with tissue stress and injury. In this sense, we investigated its levels in renal tissue after reperfusion at different time points. The IL-4-deficient mice presented a higher HO-1 mRNA expression ( 24 h: 10, 8-18; 48 h: 6, 5-8; 120 h: 3, 1-5) compared with wild-type mice ( $24 \mathrm{~h}: 7,7-10 ; 48 \mathrm{~h}: 4,4-5 ; 120 \mathrm{~h}: 2,2-8$, $\mathrm{p}<0.05$ at $48 \mathrm{~h}$ ), as well as compared with the IL-12-deficient mice ( $24 \mathrm{~h}: 1.8,1-8 ; 48 \mathrm{~h}: 2,2-7 ; 120 \mathrm{~h}: 1.6,1-2$, $\mathrm{p}<0.05$ at 24 and $48 \mathrm{~h}$ ) at all time points (fig. 3a). Interestingly, HO-1 mRNA expression decreased as time elapsed, except in the IL-12-deficient mice, where we observed a plateau even though the levels observed in animals deficient of Th2 pathway were persistently higher than the controls.

In order to demonstrate the presence of pro-inflammatory cells infiltrating the ischemic kidneys, we performed real-time PCR for a transcriptional factor unique to Th1positive cells, t-bet, and as control, for Gata-3, the transcriptional factor related to Th2-positive cells.t-bet mRNA expression was only significantly noted in the IL-4-deficient mice at $48 \mathrm{~h}$ after renal IRI $(6,5-8)$. Wild-type mice submitted to IRI also presented an expression $(4,4-5)$ lower than observed for the IL-4-deficient animals. Interestingly, t-bet expression was barely quantified in the IL12-deficient animals and even in the IL-4-deficient and wild-type animals at 24 and $120 \mathrm{~h}$ after reperfusion (fig. 3b). In a mirror pattern, Gata-3 mRNA expression was found lower in wild-type animals subjected to IRI (24 h: 1.8, 0.9-2.6; 48 h: 1.6, 1.3-1.8; 120 h: 1.6, 1.3-1.7), almost similar to those seen in IL-4-deficient animals (24 h: 1.7, 1.4-1.9; 48 h: 1.1, 0.8-1.3; 120 h: 1.7, 1.2-1.8). On the contrary, IL-12-deficient animals, protected from IRI, presented an impressive expression of Gata-3 that peaked at day 1 after reperfusion $(24 \mathrm{~h}: 4.1,3.2-6.1 ; 48 \mathrm{~h}$ : $3,2.1-4.8 ; 120$ h: $2.7,2.2-3.3$; $\mathrm{p}<0.05$ vs. wild-type animals in all points) (fig. $3 \mathrm{~d}$ ).

Monocyte and macrophage infiltration is a hallmark of IRI, partially responsible for the tissue damage. MCP-1 and its ligand, CCR2, have been documented to be present in renal IRI and to play a major role. We then investigated its role in our model by quantitative real time PCR. MCP1 mRNA expression was up-regulated very early after re- 


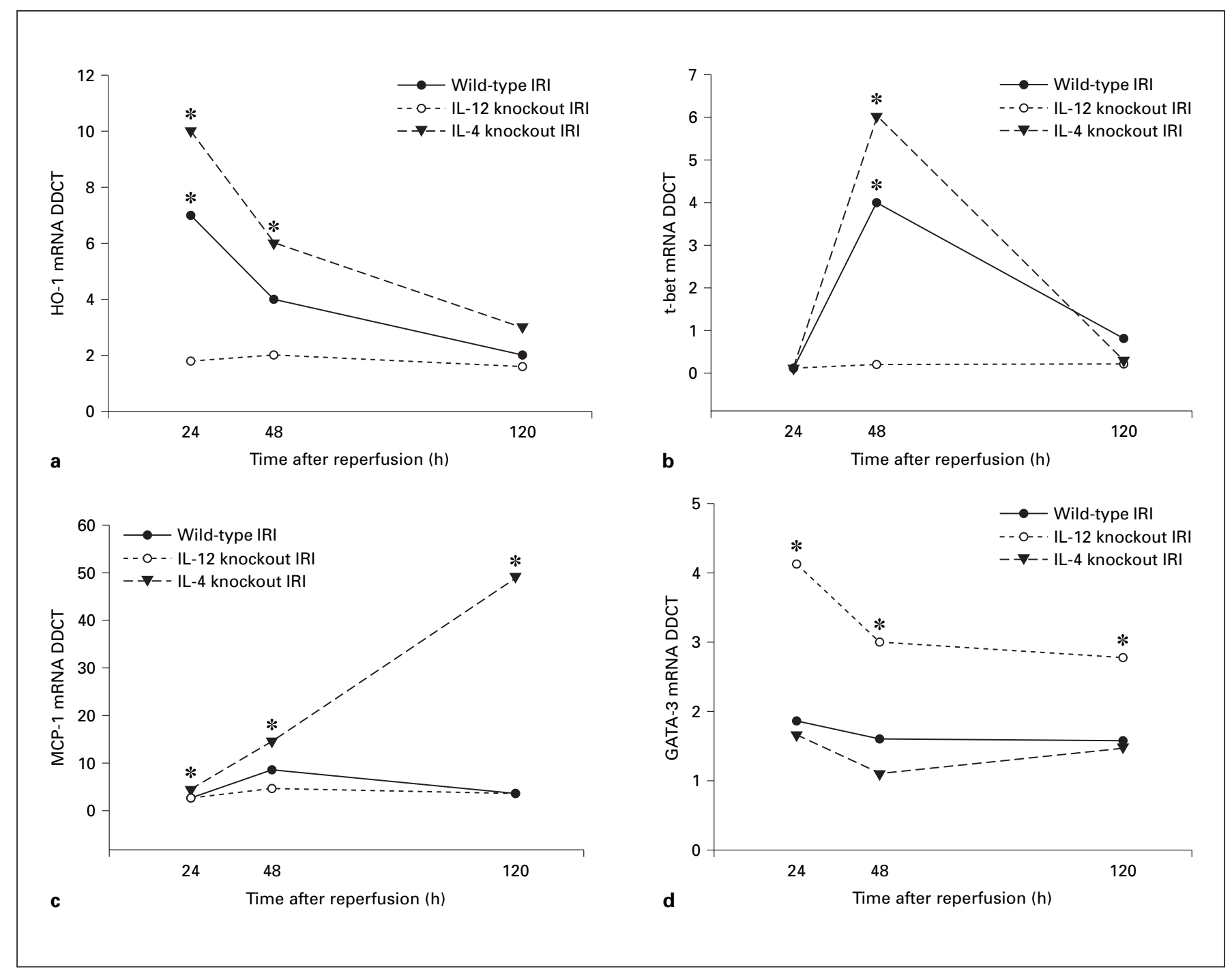

Fig. 3. Gene transcripts analyses after renal IRI. Median value of HO-1 (a), t-bet (b), MCP-1 (c), Gata-3 (d) mRNA quantified by real-time PCR in wild-type $(\bullet)$, IL-4-deficient $(\boldsymbol{\nabla})$ and IL-12-deficient $(O)$ mice at 24,48 and $120 \mathrm{~h}$ after renal IRI. Sham-operated animals showed neglected values not presented on the graphic. ${ }^{*} \mathrm{p}<0.05$, all compared with IL-12-deficient animals.

perfusion and increased with time. At all time points, in the IL-4-deficient mice, the levels were higher $(24 \mathrm{~h}: 4$, $3-10$; 48 h: 14, 7-16; 120 h: 49, 24-119) than those observed in the control animals ( $24 \mathrm{~h}: 2,1-4 ; 48 \mathrm{~h}: 8,3-12$; $120 \mathrm{~h}: 3,1-18)$. Conversely, animals that were protected against IRI (IL-12-deficient) presented with a minor upregulation. A subtle expression was observed at $24 \mathrm{~h}(2$, $1-3), 48 \mathrm{~h}(4,3-5)$ and at $120 \mathrm{~h}(3,3-6)$ after reperfusion (fig. 3c).

\section{Discussion}

Evidence of a pathogenic role for T cells in renal IRI has been demonstrated in experimental models [26, 27]. The CD4+ T cell subset was significantly identified as the important factor that mediates renal IRI with CD4+ T cells. Knockout mice or mice depleted of CD4+ T cells showed marked protection from renal IRI compared to wild-type mice [13]. In contrast, the mice deficient in the recombination activating gene 1 (RAG-1), which have no mature B or T lymphocytes, was not observed to have any 
protection, although a role for NK cell bearing CD28 was not ruled out $[12,28]$.

The underlying mechanisms by which $\mathrm{CD} 4+\mathrm{T}$ cells might mediate renal IRI are not known. The current paradigm is that CD4+ T cells have two main functional subsets, Th1 and Th 2 cells, with specific cytokine profiles and cellular responses $[16,17]$. Pro-inflammatory cytokines involved in T cell polarization, such as IFN- $\gamma$, IL- 6 and IL-2, have been reported to be up-regulated after renal ischemia [29]. CD4+ T cells can be differentiated by two distinct transcriptional regulatory factors, STAT4 and STAT6. The STAT4 pathway is activated mainly by IL-12 leading to Th1 differentiation, whereas the STAT6 pathway is activated by IL- 4 leading to Th2 differentiation [30, 31]. Recently, it was reported that STAT6-deficient mice, with a defective Th2 immune response, had an increased renal IRI, while STAT4-deficient mice, with a defective Th1 immune response, had only mildly improved renal function [18]. In an experimental model of liver IRI, the activation of STAT6 gene by IL-4 resulted in protection from liver IRI. Additionally, the contribution of STAT4 gene to liver IRI was subtle, in which protection against ischemic liver damages in STAT4-deficient mice were obtained only under the condition of an endogenous IL-12 blockade [32]. The reports that the major Th2 cytokine, IL-4, is likely a protective factor in renal IRI is consistent with the finding that another Th2 cytokine, IL-10, is also protective in renal cisplatin-induced injury [33].

On the basis of these findings, the paradigm Th1/Th2 seems to play an important role in the pathogenesis of renal IRI. We hypothesized that the deleterious effect of a Th1 immune response on renal tissue after ischemia could be related to amplification of the inflammatory surge through chemokine production and to a poor cell protective response. We subjected IL-12-deficient mice, representing defective Th1 response, and IL-4-deficient mice, representing defective Th2 response, to an experimental model of renal IRI. In addition to renal function and histological assessments, gene transcript analyses were performed to address our thesis. Finally, t-bet and Gata-3 mRNA expressions were investigated as a pattern of a Th1 and a Th2 immune response, respectively.

To address our hypothesis, we optioned to work on an IRI model in mice. This renal injury model is imperfect since we cannot study one important event that follows the ischemia, the 'no reflow phenomenon', because the cytokine knockouts are only available in mice. This imposes one problem since we cannot guarantee that Th1/ Th2 balance has also influenced the reperfusion process, adversely or not.

Th1/Th2 Cytokines and Ischemia and Reperfusion Injury
We initially observed that the IL-4-deficient mice had a higher impairment of renal function than the IL-12-deficient and wild-type mice. This was characterized by markedly higher serum urea levels, enhanced percentages of tubular necrosis and impaired tubular cell regeneration. The animals with a Th1-defective immune response behaved as CD4+ T cell-depleted animals, almost completely protected from IRI. This data corroborates the existing data on IRI $[12,14]$, and suggests that part of the protection observed in the T cell-depleted animals is due to the profile of the secreted cytokine. The data obtained with the IL-12-deficient mice clearly shows that pro-inflammatory cytokines play a negative role in IRI. As demonstrated by Tilney and colleagues, TNF-a, IFN- $\gamma$ and lymphotoxin can be found in isografts subjected to IRI $[34,35]$. In this sense, most of the detrimental effects of $\mathrm{T}$ cells in renal injury could be linked to the Th1 cytokines action. The influence of a Th 2 cytokine, IL-10, on IRI has been extensively studied by Le Moine and colleagues. Initially, in a liver cold IRI in mice, these investigators demonstrated that the IL-10 released after cold preservation of the organ was a result of reactive oxygen species production. Further on, they have shown a protective role of this cytokine in liver IRI when IL-10 was pre-administered to the donor [36-38]. Considering these findings, this data demonstrated that a Th2 milieu is associated with improvement in organ function and architecture after ischemia, while Th1 seems to be detrimental. We then questioned if the tissue injury was associated with an enhanced inflammatory immune response or a defective protective action.

Amongst the protective genes, $\mathrm{HO}-1$ has gained a lot of attention in recent years due to its great ability to restore organ function and tissue architecture after acute injury. Many investigators have elegantly demonstrated its role in IRI injury in organs such as the liver, kidney and brain [22, 39-41]. The release of a heme protein after ischemia can stimulate HO-1 activity. Although the mechanism of action is still under debate, there is a consensus that heme degradation end-products are able to give tissue protection elsewhere $[42,43]$. We observed that the IL-4-deficient mice had markedly higher expression of HO-1 mRNA compared with the IL-12-deficient mice and wildtype mice. Interestingly, the HO-1 mRNA expression in the IL-4-deficient mice diminished from 24 to $48 \mathrm{~h}$ after renal IRI, while renal dysfunction and tubular injury were still present. The link between HO-1 and Th2 cytokines is unsettled. The STAT6/STAT4 paradigm in liver IRI has been linked to HO-1 production [15]. The gene transfer of HO- 1 and IL-4 reduced IRI and delayed cardiac al- 
lograft rejection in small animals [44]. Experimental data demonstrated that HO- 1 expression could block dendritic cell maturation and thus inhibit pro-inflammatory and allogeneic immune responses via preservation of IL-10 production [45].

Although HO-1 is considered to have one protective gene, it is also a stress-inducible protein. Is this sense, $\mathrm{HO}$ 1 is a marker of tissue stress and reflects aggressive injuries. Our data showed that indeed IL- 4 knockout animals had a worse renal impairment and HO-1 early up-regulation reflected it. As IL-12 knockout animals were absolutely protected from IR, HO-1 was not up-regulated. However, when it is up-regulated before an insult takes place, HO-1 acts as cytoprotective molecule.

Monocyte/macrophage infiltration is a hallmark of IRI; however, the T cell can also be found in ischemic tissue. We investigated functionally the presence of Th1-specific cells, which could be related to pro-inflammatory cytokine production. T-bet is a transcriptional factor involved in Th1 polarization. In our model, t-bet was found at $48 \mathrm{~h}$ post-reperfusion in wild-type mice. As should be expected, IL-12-deficient animals had marginal expression. Nevertheless, animals defective in the Th2 pathway presented an elevated expression of t-bet, peaking at $48 \mathrm{~h}$. Contrary to what was seen with t-bet mRNA expression, Gata-3 mRNA analyses showed that IRI in wild-type animals is associated with an impaired Th2 response. Indeed, IL-12-deficient animals displayed a marked shift toward a Th2 profile after IRI was induced. It is well known that the Th1 pathway is inhibited by Th 2 cytokines, and vice versa, which could explain our data. In the absence of a Th2 environment, Th1-specific cells might predominate after ischemia leading to the production of Th1 cytokines that can ultimately stimulate endothelial cells.

Chemokines play a prominent role in the acute inflammatory response in several models of kidney disease. The renal tubular epithelium is capable of expressing MCP-1, favoring the renal injury determined by mononuclear infiltration in renal IRI [5]. Previously, it was reported that MCP-1 expression is increased in renal IRI of wild-type mice, correlating with monocyte/macrophage infiltration in the post-ischemic kidney [46, 47]. On the other hand, Tarzami et al. [48] have just demonstrated that treatment of cardiac myocyte cultures with MCP-1 protected them from hypoxia-induced cell death, via stimulation of ERK1/2 pathway. We then investigated its role in our model. MCP-1 mRNA expression peaked at $48 \mathrm{~h}$ in wildtype animals, decreasing thereafter. Interestingly, in the IL-4-deficient mice, it increased steadily after reperfusion, even when renal function had returned to almost normal values ( $120 \mathrm{~h}$ after reperfusion). MCP-1 production most likely occurred after stimulation of endothelial and infiltrating leukocytes presented in ischemic kidneys. This was probably induced by the release of Th1 cytokines, since it peaked after t-bet mRNA expression. In this sense, the IL-4-deficient animals create a predominant Th1 milieu in ischemic organs that favor the attraction of more inflammatory cells via MCP-1. It is noteworthy to say that the IL-12-deficient animals hardly presented MCP-1 expression.

The link between HO-1 and MCP-1 has been unraveled in recent years. Chronic inflammation induced by repetitive heme protein administration results in up-regulation of HO-1 in association with MCP-1 [49]. Stimulation by reactive oxygen species and activation of NF-kB (nuclear factor kappa B) seems to be the mediators of MCP-1-induced expression, while simultaneously enhancing HO-1 expression [46]. However, Kanakiriya et al. [50] have just demonstrated that MCP-1 could be induced in an HO-1-dependent and -independent way. Rat proximal tubular cells exposed to hemin presented an early expression of MCP-1 through redox-sensitive, HO-1-dependent and NF-kB-involved pathways. However, MCP-1 was also later expressed in $\mathrm{HO}-1$-independent pathways. Pittock et al. [51] showed that MCP-1 expression was dependent on HO-1 and NF-kB integrity pathways (the transcript factor that regulates MCP-1). Finally, corroborating with these findings, prior induction of HO-1 [23], use of NF-kB decoy oligodeoxynucleotides [52] and pioglitazone results in down-regulation of MCP-1 and an increased expression of HO-1 in IRI models [53]. Although we observed an inverse correlation between $\mathrm{HO}-1$ and MCP-1 mRNA in IL-4-deficient mice, our data cannot conclude that the later expression was inhibited by the former molecule.

Here, we demonstrated that Th1-deficient animals were completely protected from the consequences of renal IR, therefore implicating a major role for pro-inflammatory cytokines in the immune response that follows this insult. These novel insights may provide the basis for a better understanding of the pathophysiological aspects of IRI, as well as for the development of preventive and therapeutic methods for ischemic acute renal failure.

\section{Acknowledgments}

This work was supported by the Brazilian Foundation - FAPESP (Fundação de Apoio à Pesquisa do Estado de São Paulo), Grants No 04/13826-5 and 04/08311-6.

The authors have no conflict of interest. 


\section{References}

1 Thadhani R, Pascual M, Bonventre JV: Acute renal failure. N Engl J Med 1996;334:14481460.

$\checkmark 2$ Nolan CR, Anderson RJ: Hospital-acquired acute renal failure. J Am Soc Nephrol 1998;9: 710-718.

$\checkmark 3$ Cecka JM: The UNOS Scientific Renal Transplant Registry. Clin Transpl 1998:1-16.

4 Shoskes DA, Cecka JM: Deleterious effects of delayed graft function in cadaveric renal transplant recipients independent of acute rejection. Transplantation 1998;66:1697-1701.

$\checkmark 5$ Bonventre JV, Zuk A: Ischemic acute renal failure: an inflammatory disease? Kidney Int 2004, 66:480-485.

$\checkmark 6$ Friedewald JJ, Rabb H: Inflammatory cells in ischemic acute renal failure. Kidney Int 2004; 66:486-491.

7 Molitoris BA, Sutton TA: Endothelial injury and dysfunction: role in the extension phase of acute renal failure. Kidney Int 2004;66:496499.

-8 Ysebaert DK, De Greef KE, De Beuf A, Van Rompay AR, Vercauteren S, Persy VP, De Broe ME: T cells as mediators in renal ischemia/reperfusion injury. Kidney Int 2004;66:491496.

$\checkmark 9$ Chandraker A, Takada M, Nadeau KC, Peach R, Tilney NL, Sayegh MH: CD28-b7 blockade in organ dysfunction secondary to cold ischemia/reperfusion injury. Kidney Int 1997;52: 1678-1684.

-10 Takada M, Chandraker A, Nadeau KC, Sayegh $\mathrm{MH}$, Tilney NL: The role of the B7 costimulatory pathway in experimental cold ischemia/ reperfusion injury. J Clin Invest 1997;100: 1199-1203.

11 De Greef KE, Ysebaert DK, Dauwe S, Persy V, Vercauteren SR, Mey D, De Broe ME: AntiB7-1 blocks mononuclear cell adherence in vasa recta after ischemia. Kidney Int 2001;60: 1415-1427.

12 Burne-Taney MJ, Yokota-Ikeda N, Rabb H: Effects of combined T- and B-cell deficiency on murine ischemia reperfusion injury. Am J Transplant 2005;5:1186-1193.

13 Burne MJ, Daniels F, El Ghandour A, Mauiyyedi S, Colvin RB, O’Donnell MP, Rabb H: Identification of the CD4(+) T cell as a major pathogenic factor in ischemic acute renal failure. J Clin Invest 2001;108:1283-1290.

14 Yokota N, Daniels F, Crosson J, Rabb H: Protective effect of $\mathrm{T}$ cell depletion in murine renal ischemia-reperfusion injury. Transplantation 2002;74:759-763.

15 Shen XD, Ke B, Zhai Y, Gao F, Busuttil RW, Cheng G, Kupiec-Weglinski JW: Toll-like receptor and heme oxygenase-1 signaling in hepatic ischemia/reperfusion injury. Am J Transplant 2005;5:1793-1800.

-16 Abbas AK, Murphy KM, Sher A: Functional diversity of helper T lymphocytes. Nature 1996;383:787-793.
17 Agnello D, Lankford CS, Bream J, Morinobu A, Gadina M, O'Shea JJ, Frucht DM: Cytokines and transcription factors that regulate $\mathrm{T}$ helper cell differentiation: new players and new insights. J Clin Immunol 2003;23:147161.

18 Yokota N, Burne-Taney M, Racusen L, Rabb $\mathrm{H}$ : Contrasting roles for STAT4 and STAT6 signal transduction pathways in murine renal ischemia-reperfusion injury. Am J Physiol Renal Physiol 2003;285:F319-F325.

19 Camara NO, Soares MP: Heme oxygenase-1 (HO-1), a protective gene that prevents chronic graft dysfunction. Free Radic Biol Med 2005;38:426-435.

20 Kobayashi T, Sato Y, Yamamoto S, Takeishi T, Hirano K, Watanabe T, Takano K, Naito M, Hatakeyama K: Augmentation of heme oxygenase- 1 expression in the graft immediately after implantation in adult living-donor liver transplantation. Transplantation 2005; 79: 977-980.

21 Vera T, Henegar JR, Drummond HA, Rimoldi JM, Stec DE: Protective effect of carbon monoxide-releasing compounds in ischemia-induced acute renal failure. J Am Soc Nephrol 2005;16:950-958.

22 Tsuchihashi S, Fondevila C, Kupiec-Weglinski JW: Heme oxygenase system in ischemia and reperfusion injury. Ann Transplant 2004;9: 84-87.

-23 Morita T, Imai T, Yamaguchi T, Sugiyama T, Katayama S, Yoshino G: Induction of heme oxygenase-1 in monocytes suppresses angiotensin II-elicited chemotactic activity through inhibition of CCR2: role of bilirubin and carbon monoxide generated by the enzyme. Antioxid Redox Signal 2003;5:439-447.

24 Tanaka M, Mokhtari GK, Terry RD, Balsam LB, Lee KH, Kofidis T, Tsao PS, Robbins RC: Overexpression of human copper/zinc superoxide dismutase (SOD1) suppresses ischemiareperfusion injury and subsequent development of graft coronary artery disease in murine cardiac grafts. Circulation 2004;110: II200-II206.

25 Kelly KJ, Williams WW Jr, Colvin RB, Bonventre JV: Antibody to intercellular adhesion molecule 1 protects the kidney against ischemic injury. Proc Natl Acad Sci USA 1994;91: 812-816.

26 Kieran NE, Rabb H: Immune responses in kidney preservation and reperfusion injury. J Invest Med 2004;52:310-314.

$\checkmark 27$ Versteilen AM, Di Maggio F, Leemreis JR, Groeneveld AB, Musters RJ, Sipkema P: Molecular mechanisms of acute renal failure following ischemia/reperfusion. Int J Artif Organs 2004;27:1019-1029.

28 Wang B, Hollander GA, Nichogiannopoulou A, Simpson SJ, Orange JS, Gutierrez-Ramos JC, Burakoff SJ, Biron CA, Terhorst C: Natural killer cell development is blocked in the context of aberrant $\mathrm{T}$ lymphocyte ontogeny. Int Immunol 1996;8:939-949.
-29 Goes N, Urmson J, Ramassar V, Halloran PF: Ischemic acute tubular necrosis induces an extensive local cytokine response: evidence for induction of interferon-gamma, transforming growth factor-beta 1, granulocytemacrophage colony-stimulating factor, interleukin-2, and interleukin-10. Transplantation 1995;59:565-572.

30 Kaplan MH, Schindler U, Smiley ST, Grusby MJ: Stat6 is required for mediating responses to IL-4 and for development of Th2 cells. Immunity 1996;4:313-319.

>31 Kaplan MH, Sun YL, Hoey T, Grusby MJ: Impaired IL-12 responses and enhanced development of Th2 cells in Stat4-deficient mice. Nature 1996;382:174-177.

32 Kato A, Graul-Layman A, Edwards MJ, Lentsch AB: Promotion of hepatic ischemia/ reperfusion injury by IL-12 is independent of STAT4. Transplantation 2002;73:1142-1145.

>33 Deng J, Kohda Y, Chiao H, Wang Y, Hu X, Hewitt SM, Miyaji T, McLeroy P, Nibhanupudy B, Li S, Star RA: Interleukin-10 inhibits ischemic and cisplatin-induced acute renal injury. Kidney Int 2001;60:2118-2128.

34 Nagano H, Nadeau KC, Takada M, Kusaka M, Tilney NL: Sequential cellular and molecular kinetics in acutely rejecting renal allografts in rats. Transplantation 1997;63:1101-1108.

$>35$ Takada M, Nadeau KC, Shaw GD, Tilney NL: Early cellular and molecular changes in ischemia/reperfusion injury: inhibition by a selectin antagonist, P-selectin glycoprotein ligand1. Transplant Proc 1997;29:1324-1325.

$>36$ Le Moine O, Louis H, Stordeur P, Collet JM, Goldman M, Deviere J: Role of reactive oxygen intermediates in interleukin 10 release after cold liver ischemia and reperfusion in mice. Gastroenterology 1997;113:1701-1706.

37 Le Moine O, Louis H, Demols A, Desalle F, Demoor F, Quertinmont E, Goldman M, Deviere J: Cold liver ischemia-reperfusion injury critically depends on liver T cells and is improved by donor pretreatment with interleukin 10 in mice. Hepatology 2000;31:12661274.

38 Donckier V, Loi P, Closset J, Nagy N, Quertinmont E, Le Moine O, Deviere J, Goldman M, Gelin M, Gianello P: Preconditioning of donors with interleukin-10 reduces hepatic ischemia-reperfusion injury after liver transplantation in pigs. Transplantation 2003;75: 902-904.

-39 Shimizu H, Takahashi T, Suzuki T, Yamasaki A, Fujiwara T, Odaka Y, Hirakawa M, Fujita H, Akagi R: Protective effect of heme oxygenase induction in ischemic acute renal failure. Crit Care Med 2000;28:809-817.

40 Geddes JW, Pettigrew LC, Holtz ML, Craddock SD, Maines MD: Permanent focal and transient global cerebral ischemia increase glial and neuronal expression of heme oxygenase-1, but not heme oxygenase-2, protein in rat brain. Neurosci Lett 1996;210:205-208. 
-41 Sass G, Soares MC, Yamashita K, Seyfried S, Zimmermann WH, Eschenhagen T, Kaczmarek E, Ritter T, Volk HD, Tiegs G: Heme oxygenase- 1 and its reaction product, carbon monoxide, prevent inflammation-related apoptotic liver damage in mice. Hepatology 2003;38:909-918.

42 Akamatsu Y, Haga M, Tyagi S, Yamashita K, Graca-Souza AV, Ollinger R, Czismadia E, May GA, Ifedigbo E, Otterbein LE, Bach FH, Soares MP: Heme oxygenase-1-derived carbon monoxide protects hearts from transplant associated ischemia reperfusion injury. Faseb J 2004;18:771-772.

-43 Yamashita K, McDaid J, Ollinger R, Tsui TY, Berberat PO, Usheva A, Csizmadia E, Smith $\mathrm{RN}$, Soares MP, Bach FH: Biliverdin, a natural product of heme catabolism, induces tolerance to cardiac allografts. Faseb J 2004; 18 : 765-767.

-44 Vassalli G, Fleury S, Li J, Goy JJ, Kappenberger L, von Segesser LK: Gene transfer of cytoprotective and immunomodulatory molecules for prevention of cardiac allograft rejection. Eur J Cardiothorac Surg 2003;24:794-806.
45 Chauveau C, Remy S, Royer PJ, Hill M, Tanguy-Royer S, Hubert FX, Tesson L, Brion R, Beriou G, Gregoire M, Josien R, Cuturi MC, Anegon I: Heme oxygenase-1 expression inhibits dendritic cell maturation and proinflammatory function but conserves IL-10 expression. Blood 2005;106:1694-1702.

46 Rice JC, Spence JS, Yetman DL, Safirstein RL: Monocyte chemoattractant protein-1 expression correlates with monocyte infiltration in the post-ischemic kidney. Ren Fail 2002;24: 703-723.

-47 Sung FL, Zhu TY, Au-Yeung KK, Siow YL, O $\mathrm{K}$ : Enhanced MCP-1 expression during ischemia/reperfusion injury is mediated by oxidative stress and NF-kappaB. Kidney Int 2002; 62:1160-1170

48 Tarzami ST, Calderon TM, Deguzman A, Lopez L, Kitsis RN, Berman JW: MCP-1/CCL2 protects cardiac myocytes from hypoxia-induced apoptosis by a G(alpha)-independent pathway. Biochem Biophys Res Commun 2005;335:1008-1016.

49 Nath KA, Vercellotti GM, Grande JP, Miyoshi H, Paya CV, Manivel JC, Haggard JJ, Croatt AJ, Payne WD, Alam J: Heme protein-induced chronic renal inflammation: suppressive effect of induced heme oxygenase-1. Kidney Int 2001;59:106-117.
50 Kanakiriya SK, Croatt AJ, Haggard JJ, Ingelfinger JR, Tang SS, Alam J, Nath KA: Heme: a novel inducer of MCP-1 through HO-dependent and $\mathrm{HO}$-independent mechanisms. Am J Physiol Renal Physiol 2003;284:F546-F554.

51 Pittock ST, Norby SM, Grande JP, Croatt AJ, Bren GD, Badley AD, Caplice NM, Griffin MD, Nath KA: MCP-1 is up-regulated in unstressed and stressed HO-1 knockout mice: pathophysiologic correlates. Kidney Int 2005; 68:611-622.

52 Cao CC, Ding XQ, Ou ZL, Liu CF, Li P, Wang L, Zhu CF: In vivo transfection of NF-kappaB decoy oligodeoxynucleotides attenuate renal ischemia/reperfusion injury in rats. Kidney Int 2004;65:834-845.

53 Wayman NS, Hattori Y, McDonald MC, MotaFilipe H, Cuzzocrea S, Pisano B, Chatterjee PK, Thiemermann C: Ligands of the peroxisome proliferator-activated receptors (PPARgamma and PPAR-alpha) reduce myocardial infarct size. Faseb J 2002;16:1027-1040. 